\title{
Chronic Atropine Administration Diminishes the Contribution of Vasoactive Intestinal Polypeptide to Heart Rate Regulation
}

\author{
J. KUNCOVÁ, Š. FAITOVÁ, J. CAPOUCH, M. ŠTENGL, J. SLAVÍKOVÁ \\ Department of Physiology, Charles University, Plzeň, Czech Republic
}

Received July 11, 2007

Accepted September 25, 2007

On-line November 30, 2007

\begin{abstract}
Summary
Vasoactive intestinal polypeptide (VIP) is implicated in the modulation of vagal effects on the heart rate. In this study, the impact of acute and chronic atropine administration on VIP levels in rat heart atria was investigated in relation to heart rate in the course of vagus nerves stimulation. Anaesthetised control and atropinised (10 mg/kg/day for 10 days) rats pretreated with metipranolol and phentolamine that were either given or not a single dose of atropine were subjected to bilateral vagus nerve stimulation ( $30 \mathrm{~min}: 0.7 \mathrm{~mA}, 20 \mathrm{~Hz}, 0.2 \mathrm{~ms}$ ). VIP concentrations in the atria were determined after each stimulation protocol. In control rats with or without single atropine administration, the heart rate upon vagal stimulation was higher than in atropinised animals with or without single atropine dose, respectively. VIP concentrations in the control atria were significantly decreased after the stimulation; the decrease was comparable both in the absence and presence of a single dose of atropine. Compared to controls, VIP levels were significantly decreased after chronic atropine treatment and they were not further reduced by vagal stimulation and single atropine administration. Administration of VIP antagonist completely abolished the differences in the heart rate upon vagal stimulation between control and atropinised groups. In conclusion, the data indicate that chronic atropine administration affects VIP synthesis in rat heart atria and consequently it modifies the heart rate regulation.
\end{abstract}

\section{Key Words}

Vasoactive intestinal polypeptide $\bullet$ Atropine $\bullet$ Heart atria $\bullet$ Vagus nerve stimulation • Rat

\section{Corresponding author}

J. Kuncová, Department of Physiology, Charles University, Lidická 1, 30100 Plzeň, Czech Republic. Fax: +420 377593349. E-mail: jitka.kuncova@lfp.cuni.cz

\section{Introduction}

Vasoactive intestinal polypeptide (VIP), a 28-amino-acid peptide originally isolated from the porcine small intestine (Said and Mutt 1970), shows widespread distribution in both central and peripheral nervous systems (Said 1984). It is co-localised with acetylcholine in postganglionic parasympathetic neurones in the cardiovascular, digestive, urogenital, and respiratory systems (Lundberg 1996). In the mammalian heart, VIP was found in nerve fibres associated with atrial and ventricular myocardium, conduction system, and coronary vessels (Della et al. 1983, Brum et al. 1986, Anderson et al. 1992, Gulbenkian et al. 1993). However, VIP immunoreactivity has also been demonstrated in neuronal cell bodies of the intrinsic cardiac ganglia that did not possess cholinergic phenotype (Horáčková et al. 2000, Kuncová and Slavíková 2003) and belong to the population of nonadrenergic noncholinergic local circuit neurones integrating the efferent input to the heart with sensory information from cardiac receptors (Armour 1999).

It is well established that in the canine heart, VIP is released upon high frequency electrical stimulation of the vagus nerve (Anderson et al. 1993, 1994). In the presence of atropine, it mediates positive chronotropic effect known as vagal tachycardia (Hill et al. 1995, Henning et al. 1996) that may act as a safeguard mechanism preventing cardiac arrest during strong vagal activity (Roossien et al. 1997). The peptide also increases myocardial contractility and relaxes coronary vascular smooth muscle, thereby improving cardiac perfusion (Henning and Sawmiller 2001).

In the rat heart, vasodilatory and cardio- 
protective effects of VIP have been repeatedly documented. In the isolated ischemic reperfused hearts, VIP dose-dependently enhanced coronary blood flow and reduced myocardial tissue injury, intracellular $\mathrm{Ca}^{2+}$ transients, and the level of hydroxyl radicals (Kalfin et al. 1994, Das et al. 1998). In contrast, the role of VIP in the direct regulation of the heart rate and myocardial contractility seems to be less convincing, since VIP applied externally to the isolated right atrium did not increase the heart rate significantly (Hogan and Markos 2006a). In the isolated heart perfused by the Langendorff technique, the vasodilatory effect of VIP occurred without a significant change in the heart rate, myocardial contractility or oxygen consumption (Sawmiller et al. 2004). In addition, the positive chronotropic effect of the vagus nerve stimulation in the presence of atropine was inconsistent in the isolated whole heart (Shvilkin et al. 1994). Recently, Hogan and Markos (2006b) have suggested that VIP exerts a vagal cholinergic inhibitory effect at the level of the preganglionic-postganglionic synapse in the isolated rat right atrium, the finding supporting rather neuromodulatory role of VIP in the rat heart than a direct stimulatory effect on the sinoatrial cells.

Studies on the inverse relationship, i.e. the effects of acetylcholine or its antagonists on VIP-ergic neurotransmission have shown that muscarinic receptor antagonist atropine stimulated VIP release from the postganglionic parasympathetic fibres via presynaptic muscarinic autoreceptors in the rat, cat, and ferret salivary glands (Lundberg 1981, Lundberg et al. 1981, Tobin et al. 1991, 1994, Asztely et al. 1996). The effect of acetylcholine or atropine on VIP release or synthesis in the mammalian heart has not been studied yet.

VIP concentration in the mammalian heart is extremely low (Fahrenkrug 1979). Thus, it is very difficult to measure VIP release in small rodents directly. However, the co-existence of VIP and acetylcholine in the intrinsic cardiac neurones and the presence of muscarinic receptors on postganglionic parasympathetic fibre terminals (Löffelholz and Pappano 1985) give rise conditions for putative effects of acetylcholine and/or its antagonists on VIP-ergic neurotransmission.

Therefore, the aims of the present study were to confirm whether vagal tachycardia can be elicited in the anaesthetised rat and whether acute or chronic administration of atropine could affect VIP release and/or synthesis in rat heart atria. We have performed experiments on rats subjected to atropine or saline administration for 10 days followed by bilateral vagus nerve stimulation accompanied or not by atropine pretreatment. After the end of experiments, atria were excised and extracted for determination of VIP levels. The data confirm that VIP is involved in the regulation of the heart rate under excessive vagus nerve stimulation and suggest that muscarinic cholinergic receptors might be implicated in the regulation of the peptide synthesis in the rat heart.

\section{Methods}

Wistar rats purchased from VELAZ (Czech Republic) at the age of 60 days were used. The animals were housed five per cage, fed standard laboratory chow with free access to drinking water. All animals were left intact to adapt for two weeks before the initiation of the experiments. All experiments were conducted in accordance with the relevant Guidelines of the Czech Ministry of Agriculture for scientific experimentation on animals and the European Directive for the Protection of Vertebrate Animals Used for Experimental and Other Scientific Purposes (86/609/EU) and were approved by the University Committee for Experiments on Laboratory Animals (Charles University, Czech Republic). Rats were randomly divided into two groups. Atropinised rats received once a day subcutaneous injection of atropine sulphate $10 \mathrm{mg} / \mathrm{kg}$ for 10 days; control animals were treated with saline in corresponding volumes for 10 days.

\section{Measurement of the resting heart rate}

One day after the last injection, the resting heart rates were measured in 6 atropinised and 6 control animals. Rats were placed in a small chamber and their heart rates were recorded using electrocardiograph (SEIVA EKG Praktik II, Veterinary version, Czech Republic) with electrodes located in the floor of the chamber. Repeated measurements of the heart rate were made until stable values were reached. The values mentioned in the results represent the means of these measurements.

\section{Stimulation of the vagus nerves}

The rats were anaesthetised with urethane 1.2 $\mathrm{g} / \mathrm{kg}$, i.p. and artificially ventilated. A sterile glass cannula was inserted into the trachea and animals were ventilated with air using Pressure Controlled Ventilator (Kent Scientific, USA). The ventilation was adjusted to 90 strokes per minute; peak inspiratory pressure $12 \mathrm{~cm}$ 
Table 1. Overview of the experimental groups.

\begin{tabular}{|c|c|c|}
\hline Group & Intervention & n \\
\hline C1 & Anaesthesia, bilateral vagotomy, metipranolol + phentolamine & 6 \\
\hline$A 1$ & Anaesthesia, bilateral vagotomy, metipranolol + phentolamine & 6 \\
\hline \multirow[t]{3}{*}{$C 2$} & Anaesthesia, bilateral vagotomy, metipranolol + phentolamine, bilateral vagus nerve stimulation & \\
\hline & a) none & 7 \\
\hline & b) VIP antagonist administered prior to the onset of stimulation $(2 \mu \mathrm{g} / \mathrm{kg}$, i.v. $)$ & 5 \\
\hline \multirow[t]{3}{*}{$A 2$} & Anaesthesia, bilateral vagotomy, metipranolol + phentolamine, bilateral vagus nerve stimulation & \\
\hline & a) none & 7 \\
\hline & b) VIP antagonist administered prior to the onset of stimulation & 5 \\
\hline \multirow[t]{3}{*}{ C3 } & $\begin{array}{l}\text { Anaesthesia, bilateral vagotomy, metipranolol }+ \text { phentolamine }+ \text { atropine, bilateral vagus nerve } \\
\text { stimulation }\end{array}$ & \\
\hline & a) none & 7 \\
\hline & b) VIP antagonist administered prior to the of stimulation & 5 \\
\hline \multirow[t]{3}{*}{$A 3$} & $\begin{array}{l}\text { Anaesthesia, bilateral vagotomy, metipranolol }+ \text { phentolamine }+ \text { atropine, bilateral vagus nerve } \\
\text { stimulation }\end{array}$ & \\
\hline & a) none & 7 \\
\hline & b) VIP antagonist administered prior to the onset of stimulation & 5 \\
\hline
\end{tabular}

A - atropinised rats; C - controls (see text).

$\mathrm{H}_{2} \mathrm{O}$; inspiration duration $45 \%$ of the total breath cycle length. Subcutaneous peripheral limb electrodes were inserted and an electrocardiogram (ECG) was continuously recorded for the entire duration of the experiment. Jugular vein was cannulated using a sterile polyethylene catheter. Both cervical vagus nerves were carefully isolated, decentralised and prepared for subsequent stimulation. Six animals from both control and atropinised groups were injected with a non-specific $\beta$-adrenergic antagonist metipranolol $2 \mathrm{mg} / \mathrm{kg}$, i.v. and non-specific $\alpha$-adrenergic antagonist phentolamine $2 \mathrm{mg} / \mathrm{kg}$, i.v. These rats were ventilated for further $40 \mathrm{~min}$ without any other intervention. Another 12 animals from each group were pretreated with the same doses of metipranolol and phentolamine and they were subjected to continuous $30 \mathrm{~min}$ lasting bilateral vagus nerve stimulation (ISOSTIM A 320, WPI, USA) by rectangular impulses $0.7 \mathrm{~mA}$, duration $2 \mathrm{~ms}$ and frequency $20 \mathrm{~Hz}$. The immediate effect of atropine was studied on another 12 rats from both control and atropinised groups that were pretreated with metipranolol, phentolamine and atropine $10 \mathrm{mg} / \mathrm{kg}$, i.v. and their vagus nerves were stimulated with the same intensity and duration as in the previous group. Five animals from each stimulated subgroup were injected with a $2 \mu \mathrm{g} / \mathrm{kg}$ bolus of VIP antagonist just prior to the onset of the vagus nerves stimulation. A detailed scheme of experimental groups and interventions is shown in Table 1.

\section{Dissection and extraction of VIP}

Atropinised and control rats after the stimulation experiments were killed by decapitation and their hearts were rapidly excised and rinsed with ice-cold $155 \mathrm{mmol} / \mathrm{l}$ $\mathrm{NaCl}$. The heart atria were dissected, cleaned of connective tissue and fat and separated into the left atria with interatrial septum and the right atria. Immediately after dissection, tissues were frozen on the dry ice and weighed. Then the samples were placed in $0.1 \mathrm{~mol} / 1 \mathrm{HCl}$ containing $100 \mu \mathrm{mol} / 1$ EDTA and $0.01 \% \mathrm{Na}_{2} \mathrm{~S}_{2} \mathrm{O}_{5} \quad 1: 10(\mathrm{w} / \mathrm{v})$ and briefly pulverised. Test tubes with tissues were heated in water bath $95{ }^{\circ} \mathrm{C}$ for $15 \mathrm{~min}$ and then cooled on ice. The content of tubes was homogenised $30 \mathrm{~s}$ using Ultra-Turrax homogeniser. The homogenate was centrifuged at 10,000 $\mathrm{g}, 4^{\circ} \mathrm{C}, 20 \mathrm{~min}$. The supernatant was neutralised with 1 
mol/1 Tris-base and centrifuged again at 5,000 g, $4{ }^{\circ} \mathrm{C}, 15$ min. The clear supernatant was aspirated and stored at $-70^{\circ} \mathrm{C}$ until radioimmunoassay (RIA).

\section{Biochemical assays}

VIP-immunoreactivity was assayed in tissue extracts by RIA using commercial kits (Phoenix Pharmaceuticals, USA). Assay tubes were set up in duplicate, each containing $100 \mu$ of unknown sample or standard and $100 \mu \mathrm{l}$ of rabbit anti-peptide serum (crossreactivity in \%: VIP 100; VIP-fragment 10-28 100; PACAP-27 0.02; VIP fragment 1-12, PHM-27, substance $\mathrm{P}$, endothelin-1, secretin, glucagon, galanin, somatostatin, PACAP-38 0). Tubes were vortexed and incubated $20 \mathrm{~h}$ at $4{ }^{\circ} \mathrm{C}$. After incubation, $100 \mu \mathrm{l}$ of tracer solution was added to each tube and tubes were incubated for further 20 hours at $4{ }^{\circ} \mathrm{C}$. Bound radioactivity was separated by adding goat anti-rabbit $\mathrm{IgG}$ serum and centrifugation at $1700 \mathrm{~g}$ for $20 \mathrm{~min}$ at $4{ }^{\circ} \mathrm{C}$.

Recovery was assessed in another set of measurements by addition of exogenous VIP at the time of heating in $\mathrm{HCl}$. About $75 \%$ of added exogenous VIP could be detected in the final extract. Results were not corrected for recovery.

\section{Solutions and drugs}

Atropine sulphate, urethane and were purchased from Sigma (St Louis, MO, USA) and they were dissolved in sterile $0.9 \%$ sodium chloride solution. Metipranolol and phentolamine were obtained from Hoechst-Biotika, Slovak Republic and Novartis, Switzerland, respectively.

\section{Data analysis}

Results are presented as means \pm S.E.M. Tissue content of VIP is expressed in $\mathrm{ng} / \mathrm{g}$ tissue wet weight. Statistical differences were tested by unpaired two-tailed Student's t-test or by analysis of variance (ANOVA) followed by post hoc Fisher's Least Significant Difference test, using software package STATISTICA $\mathrm{Cz}$, version 7 (StatSoft, Inc., 2004). Normality of populations and homogeneity of variances were tested before each ANOVA. The results were considered significantly different when $\mathrm{p}<0.05$.

\section{Results}

The average body weight of the control rats was $254 \pm 5 \mathrm{~g}(\mathrm{n}=31)$ and it did not significantly differ

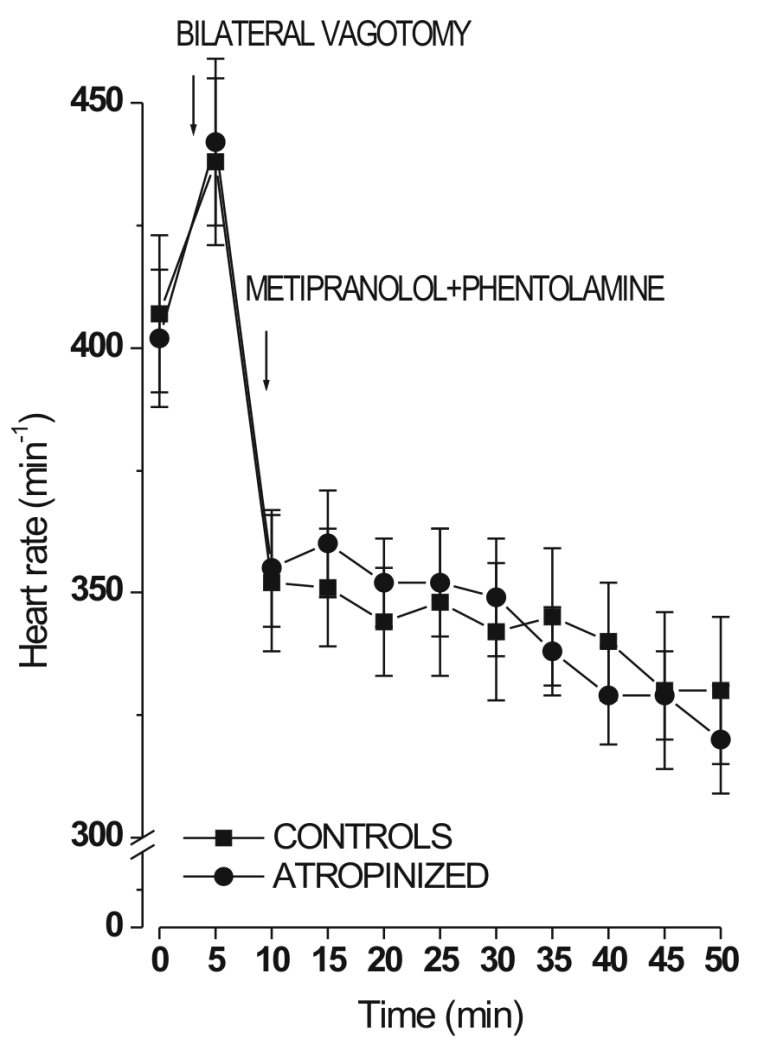

Fig. 1. Heart rate of anaesthetised control and atropinised rats after bilateral cervical vagotomy and administration of metipranolol $2 \mathrm{mg} / \mathrm{kg}$ and phentolamine $2 \mathrm{mg} / \mathrm{kg}$.

from the body weight of animals subjected to atropine administration for 10 days $(245 \pm 5 \mathrm{~g} ; \mathrm{n}=33)$. The mean value of the resting heart rate measured in atropinised animals 1 day after the last drug administration $(377 \pm 17$ $\left.\min ^{-1} ; n=6\right)$ was not significantly different as compared to that obtained from control rats $\left(368 \pm 14 \mathrm{~min}^{-1} ; \mathrm{n}=6\right)$. Figure 1 shows the data received from 6 control and 6 atropinised animals that were anaesthetised, subjected to bilateral cervical vagotomy, metipranolol and phentolamine administration and then they were left intact for further $40 \mathrm{~min}$. The heart rate of anaesthetised animals was slightly, but not significantly higher (407 $\pm 16 \mathrm{~min}^{-1}$ and $402 \pm 14 \mathrm{~min}^{-1}$ for controls and atropinised rats, respectively) than the resting heart rate measured in the intact rats. Bilateral cervical vagotomy further increased the heart rate in both experimental groups; however, the difference did not reach statistical significance compared to previous value. Administration of metipranolol and phentolamine led to a significant decrease in the heart rate in both control $\left(352 \pm 14 \mathrm{~min}^{-1}\right)$ and atropinised rats $\left(355 \pm 12 \mathrm{~min}^{-1}\right.$; $\mathrm{p}<0.05$ compared to the value just after vagotomy). The heart rate slightly decreased in the course of following 


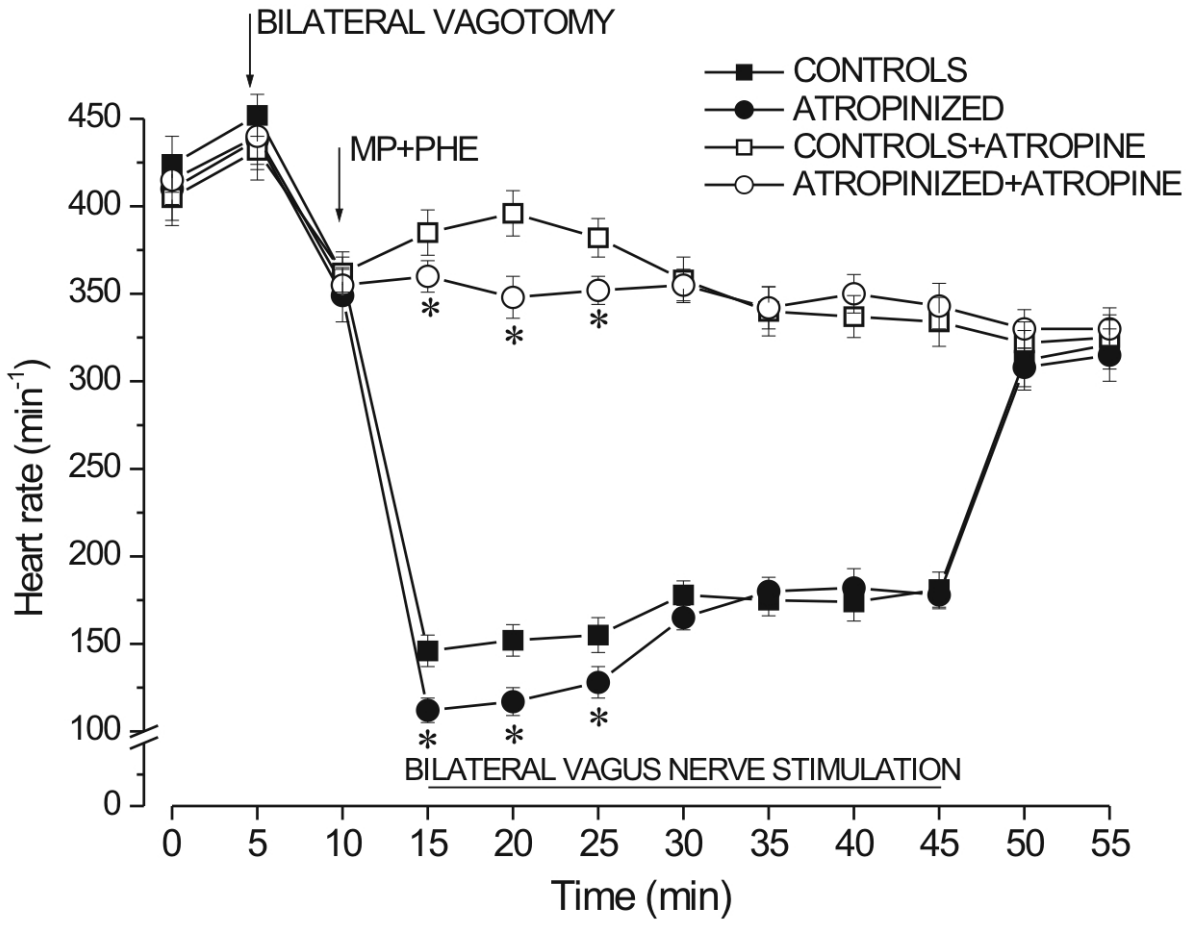

Fig. 2. The effect of electrical vagal stimulation applied for $30 \mathrm{~min}$ (0.7 $\mathrm{mA}, 20 \mathrm{~Hz}, 2 \mathrm{~ms}$ ) between times 15 and $45 \mathrm{~min}$ on the heart rate of control and atropinised anaesthetised rats after bilateral vagus nerve decentralization (5 $\mathrm{min}$ ) and administration of metipranolol $2 \mathrm{mg} / \mathrm{kg}$ and phentolamine $2 \mathrm{mg} / \mathrm{kg}$ (MP+PHE; $10 \mathrm{~min}$ ) in comparison to the heart rate recorded in anaesthetised control and atropinised rats after bilateral vagotomy, administration of metipranolol, phentolamine and atropine $10 \mathrm{mg} / \mathrm{kg}$. All values are mean \pm S.E.M. $* p<0.05$, compared to the respective value recorded in control animals.
$40 \mathrm{~min}$, reaching $330 \pm 15 \mathrm{~min}^{-1}$ (controls) and $320 \pm 11$ $\min ^{-1}$ (atropinised), which was not significantly different from the value measured after metipranolol and phentolamine administration.

\section{The effect of vagus nerve stimulation on the heart rate}

Figure 2 summarizes the data obtained from control and atropinised rats that were anaesthetised, underwent bilateral cervical vagotomy, metipranolol and phentolamine administration and they were either injected or not with a single dose of atropine. All animals were then subjected to bilateral vagus nerve stimulation lasting $30 \mathrm{~min}$. Electrical vagal stimulation resulted in a profound decrease in the heart rate in both control and atropinised rats that were not pretreated with atropine ( $n=7$ per group). However, the mean value of the heart rate just after the onset of stimulation was significantly higher in the control rats $\left(146 \pm 9 \mathrm{~min}^{-1}\right)$ than in the atropinised animals $\left(112 \pm 7 \mathrm{~min}^{-1} ; \mathrm{p}<0.05\right)$. The effect of stimulation gradually decreased resulting in $181 \pm 10 \mathrm{~min}^{-1}$ and $178 \pm 8 \mathrm{~min}^{-1}$ in the control and atropinised rats, respectively.

In the group of control rats pre-treated with metipranolol, phentolamine and atropine $(n=7)$, electrical stimulation of the vagus nerves caused slight increase in the heart rate that was not significantly different when compared to the value obtained just before the stimulation; however, it was significantly higher than the heart rate measured in atropinised animals $(n=7)$. Toward the end of experiment, vagus stimulation failed to evoke positive chronotropic effect.

The effect of vagus nerve stimulation and chronic atropine treatment on atrial VIP levels

The tissue levels of VIP were higher in the left atria than in the right ones $(p<0.05)$ and the difference remained significant in all experimental groups. Expressed in $\mathrm{ng} / \mathrm{g}$ tissue wet weight, VIP concentrations in the atria of control rats after anaesthesia, vagus nerves decentralization and metipranolol and phentolamine administration that were not subjected to vagal stimulation were $3.68 \pm 0.28$ in the right atria and $4.68 \pm 0.34$ in the left ones. Bilateral vagus nerve stimulation led to a significant decrease in VIP tissue levels that represented $\sim 60$ and $\sim 70 \%$ of the control values in the right and left atria, respectively. Single atropine administration prior to the vagal stimulation had no further effect on atrial VIP concentrations in the control rats.

Administration of atropine for 10 days resulted in a significant decrease in VIP concentrations in both atria $(p<0.05)$. Compared to the control values, VIP levels after chronic atropine treatment were reduced by $45 \%$ and $43 \%$ in the left and right atria, respectively (Fig. 3). Vagus nerve stimulation both accompanied or not with administration of atropine did not lead to any further changes in VIP concentrations in the atria of atropinised animals. 

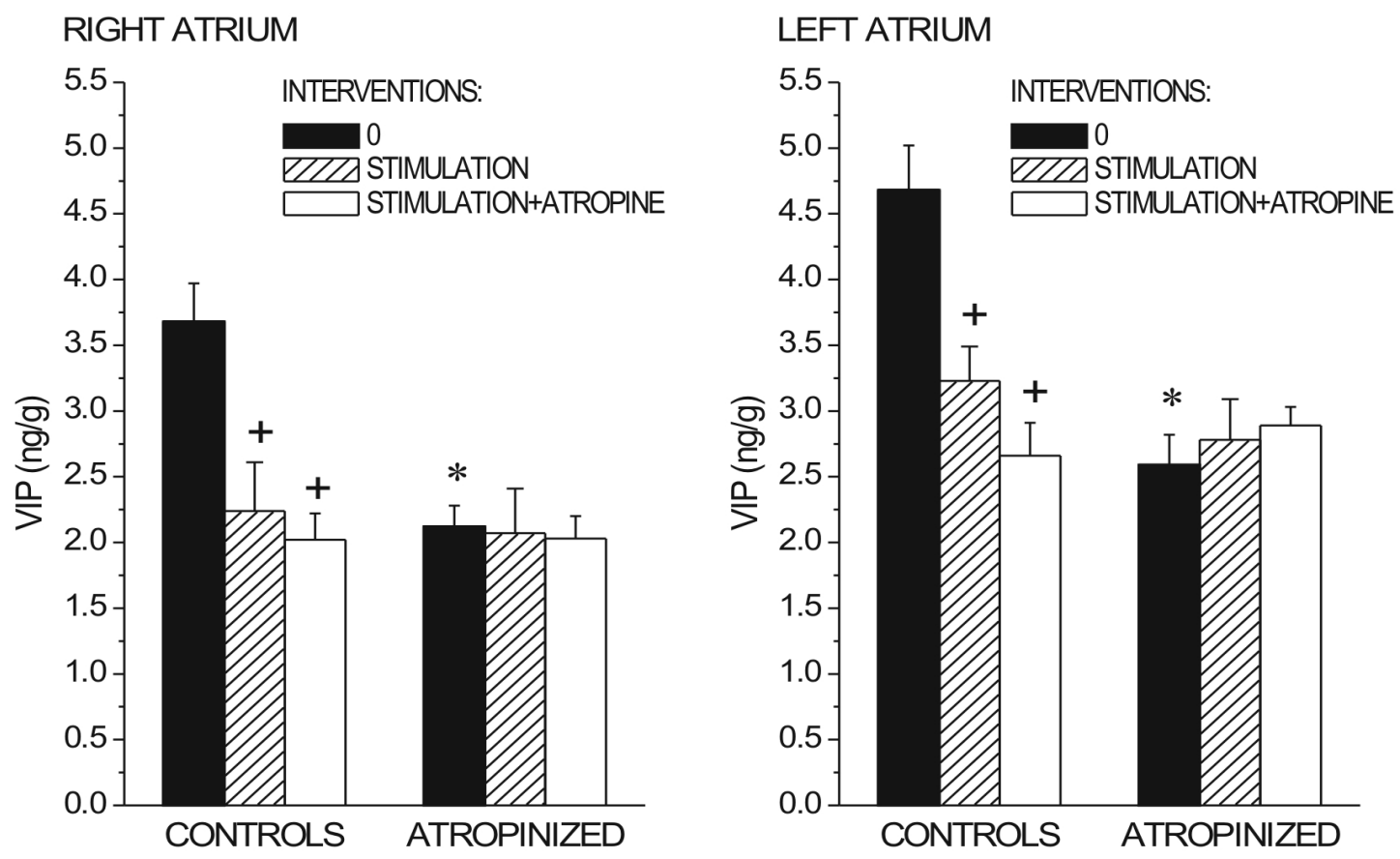

Fig. 3. VIP concentrations in the right and left atria after various interventions. $0=$ anaesthetised control and atropinised rats $(10 \mathrm{mg} / \mathrm{kg} /$ day for 10 days) with decentralised vagus nerves pretreated with metipranolol and phentolamine and artificially ventilated for $50 \mathrm{~min}$. STIMULATION = anaesthetised, artificially ventilated control and atropinised animals with decentralised vagus nerves pretreated with metipranolol and phentolamine after the bilateral vagal stimulation lasting $30 \mathrm{~min}$. STIMULATION + ATROPINE $=$ anaesthetised, artificially ventilated rats subjected to bilateral cervical vagotomy, administration of metipranolol, phentolamine and atropine and bilateral stimulation of both vagus nerves lasting $30 \mathrm{~min}(\mathrm{n}=7)$. VIP concentrations (mean \pm S.E.M.) are expressed in $\mathrm{ng} / \mathrm{g}$ tissue wet weight. $* p<0.05$, atropinised rats compared to the respective controls, ${ }^{+} p<0.05$, compared to VIP concentration obtained from control samples without any intervention.
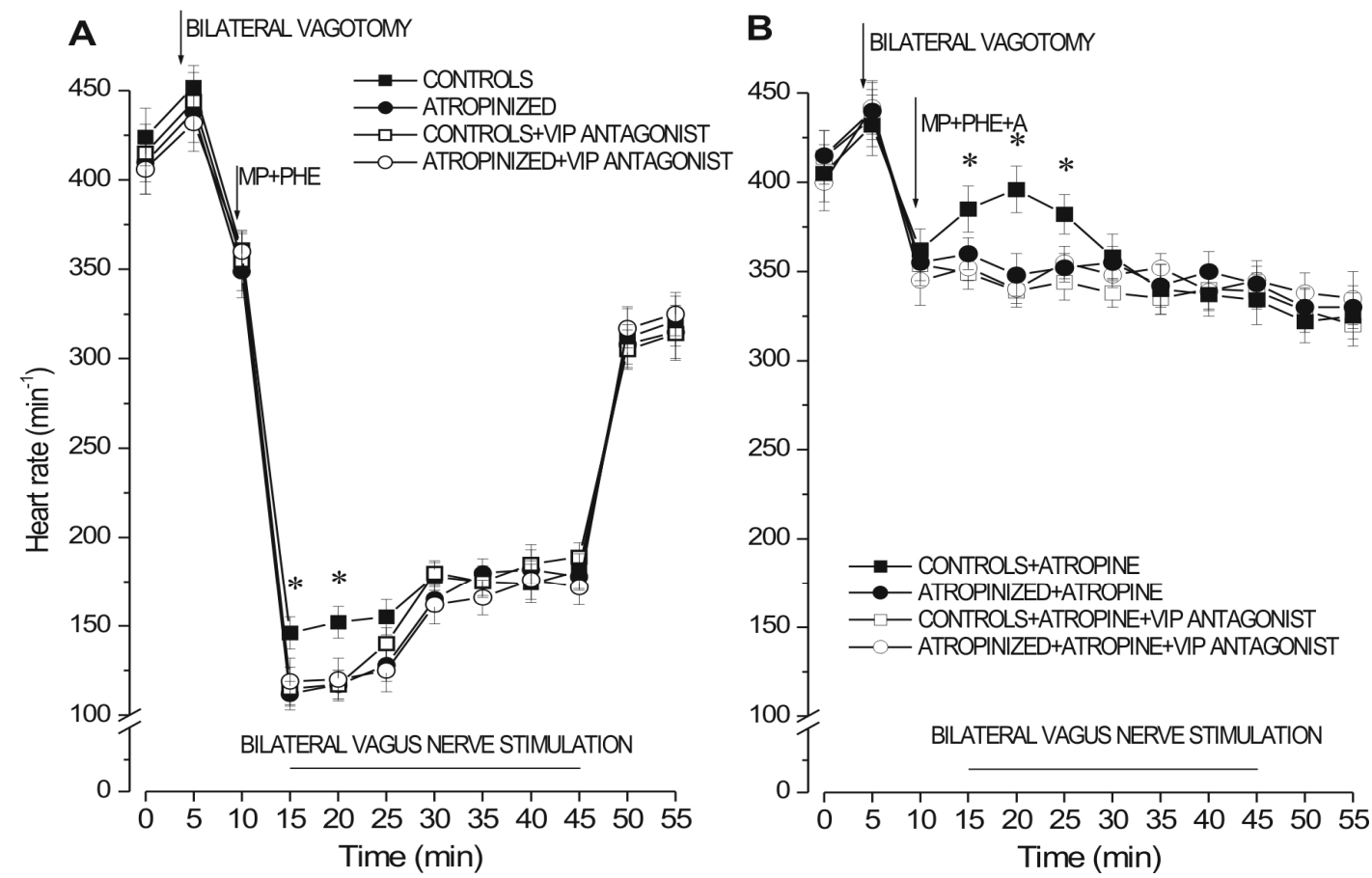

Fig. 4. The effect of VIP antagonist ([D-p-Cl-Phe ${ }^{6}$,Leu $\left.{ }^{17}\right]-\mathrm{VIP}, 2 \mu \mathrm{g} / \mathrm{kg}$, i.v.) administered just before the onset of 30 min lasting bilateral vagus nerve stimulation on the heart rate of anaesthetised control and atropinised rats subjected to the stimulation of both cervical vagus nerves by rectangular impulses $(0.7 \mathrm{~mA}, 20 \mathrm{~Hz}, 2 \mathrm{~ms})$ for $30 \mathrm{~min}$ (time 15-45 min). A: Data from animals pretreated with metipranolol $2 \mathrm{mg} / \mathrm{kg}$ and phentolamine $2 \mathrm{mg} / \mathrm{kg}(\mathrm{MP}+\mathrm{PHE}$; time $10 \mathrm{~min}$ ); the data for control and atropinised rats are the same as shown in Fig. 2. B: Data from rats pretreated with metipranolol $2 \mathrm{mg} / \mathrm{kg}$, phentolamine $2 \mathrm{mg} / \mathrm{kg}$ and atropine $10 \mathrm{mg} / \mathrm{kg}(\mathrm{MP}+\mathrm{PHE}+\mathrm{A}$; time $10 \mathrm{~min}$ ); the data for control and atropinised rats injected with a single dose of atropine are the same as shown in Fig. 2. $* \mathrm{p}<0.05$, compared to the respective value recorded in control animals injected with VIP antagonist. 
Effect of VIP antagonist on the heart rate in control and atropinised rats in the course of bilateral vagus nerve stimulation

When VIP antagonist ([D-p-Cl-Phe ${ }^{6}$, Leu $\left.^{17}\right]$-VIP, $2 \mu \mathrm{g} / \mathrm{kg}$, i.v.) was administered just before the onset of the vagus nerves stimulation to control animals pretreated with metipranolol and phentolamine, their heart rates were significantly lower $\left(115 \pm 12 \mathrm{~min}^{-1} ; \mathrm{n}=5\right)$ than those of animals undergoing stimulation alone $\left(146 \pm 9 \mathrm{~min}^{-1}\right)$. However, within $10 \mathrm{~min}$ of continuous stimulation, the heart rates of both groups were comparable. In contrast, VIP antagonist had no effect on the heart rate of rats treated with atropine for 10 days prior to the stimulation experiments ( $\mathrm{n}=5$; Fig. 4A). Similarly, in the group of rats pre-treated with metipranolol, phentolamine and atropine, VIP antagonist abolished the positive chronotropic effect of bilateral vagus nerve stimulation in control rats $(\mathrm{n}=5)$, whereas it had no effect on the heart rate in atropinised animals ( $\mathrm{n}=5$; Fig. 4B).

\section{Discussion}

The major finding of the present study is that chronic administration of muscarinic receptor antagonist atropine has substantial impact on the course of $30 \mathrm{~min}$ lasting bilateral vagus nerve stimulation and on VIP concentrations in the rat heart atria. In the control rats, the heart rate after the onset of vagal stimulation was transiently higher than in atropinised animals and this effect was abolished by administration of VIP antagonist.

It is well documented that acute administration of muscarinic receptor atropine to intact rat leads to a transient increase in the heart rate that is not accompanied by changes in the number of muscarinic receptors (Uno et al. 1991). In contrast, chronic administration of muscarinic receptors agonists or antagonists could affect not only muscarinic receptor expression (Cawley et al. 1993), but also other signalling pathways. It has been documented that in the rat heart, chronic atropine treatment increases $A_{1}$ adenosine receptors level that is associated with the enhanced negative dromotropic response to adenosine (Balas et al. 2002). In addition, although chronic hyperstimulation of cardiac muscarinic receptors brought about down-regulation of muscarinic acetylcholine receptors and also down-regulation of $\beta$-adrenergic receptors in the rat heart, the heart rate was surprisingly stable, suggesting that the heart and the neural regulatory apparatus have a remarkable capacity of coping with extreme fluctuations in neurotransmitter receptor activation (Mysliveček et al. 1996). Accordingly, our results show that chronic atropine treatment had no sustained effect on the resting heart rate since its value measured $24 \mathrm{~h}$ after the last drug administration did not significantly differ from that obtained in control rats. However, chronic atropine treatment could interfere with more subtle mechanisms of chronotropic regulation that seem to become functional under extreme situations. Neuropeptides (including VIP) are not released under basal conditions, but become synthesised in increasing amounts and are released only upon activation at high frequency firing (Hokfelt 1992). The data shown in the present study provide new evidence that also VIP signalling system might be affected via chronic inhibition of muscarinic receptors.

As shown in the results section, VIP content in the atria was significantly decreased to similar extent after both electrical vagal stimulation and chronic atropine treatment. Interestingly, in all experimental groups, VIP concentrations were significantly higher in the left atria than in the right atrial preparations. This finding seems to be in contrast to the fact that VIP is regarded as a co-transmitter of acetylcholine in parasympathetic postganglionic fibres supplying the heart that are substantially more numerous in the right atria than in the left ones (Mabe et al. 2006). The role of VIP as a co-transmitter of parasympathetic postganglionic fibres in the heart was evidenced by functional studies in different species (Shvilkin et al. 1994, Feliciano and Henning 1998) and by direct measurement of VIP output into the cardiac lymph after high frequency vagal stimulation in the canine heart (Anderson et al. 1993, 1994). However, numerous immunohistochemical studies suggested VIP localisation not only in the parasympathetic postganglionic neurones, but also in cardiac nonadrenergic noncholinergic intrinsic (Forsgren 1989, Steele et al. 1996, Horáčková et al. 1999, Kuncová and Slavíková 2003), cervicothoracic ganglionic (Heym et al. 1984) and parasympathetic preganglionic neurones (Slavíková 1997, Parsons et al. 2006). Our findings of different VIP concentrations in the rat atria are in agreement with immunohistochemical studies that have shown higher density of VIP-ergic nerve cell bodies in the rat left atria than in the right ones (Kuncová and Slavíková 2003). Also in the canine heart, VIP concentrations measured by radioimmunoassay were higher in the left atria than in the right ones and were not affected by total cardiac denervation, another finding suggesting multiple origin of VIP (Anderson et al. 1993). 
It is thus probable that VIP release and/or synthesis are differentially regulated in distinct neuronal types.

Decrease in VIP tissue content after atropine treatment could be due to: a) greater degradation of VIP or b) increased release of VIP leading to a depletion of the intracellular pool of the peptide and/or c) decreased synthesis of the peptide.

It has been already demonstrated that atropine does not influence degradation of VIP (Lundberg 1981). The decrease in VIP content after high frequency parasympathetic stimulation was reported in the rat salivary gland (Tobin et al. 1994) and proposed in the canine heart where a diminished vagally induced tachycardia was correlated with the reduction in VIP efflux that probably reflected depletion of this peptide from the vagus nerve endings consequent to the prolonged neural stimulation (Hill et al. 1995). The present data confirmed that high frequency stimulation of the decentralised vagus nerves led to $30-40 \%$ reduction in VIP concentrations in the rat heart atria. However, single administration of atropine prior to vagal stimulation did not result in any further changes of VIP concentrations in the atria. Endogenously released acetylcholine has been suggested to exert a negative feedback effect on the postganglionic varicosities that release both acetylcholine and VIP in the rat salivary glands and in the rat and porcine pancreas (Lundberg et al. 1981, Barrett et al. 1993, Tobin et al. 1994, Halfacree et al. 2001). In contrast, VIP release during vagus nerve stimulation was not influenced by atropine in the canine pancreas (Havel et al. 1997). In addition, atropine even reduced the VIP output into the portal plasma evoked by intraduodenal infusion of lactic acid (Sanchez-Vicente et al. 1995) as well as the peptide release from porcine ileum segments in response to liquid infusion (Schmidt et al. 1993). Thus, the inhibitory effect of muscarinic receptor agonists on VIP release from the cholinergic neurones co-storing VIP is not uniform for various organs and species. The present study shows that VIP release from the rat heart atria, although at least partly mediated by vagus nerve stimulation, did not seem to be modulated by atropine.

Direct impact of muscarinic receptor agonist carbamylcholine on VIP gene expression was demonstrated in human neuroblastoma cells (Kristensen et al. 1997). Also, in the rat frontal cortical slices, incubation with atropine did not alter VIP release, but long-term atropine treatment resulted in a decreased content of VIP (Lapchak and Beaudet 1990). In addition, chronic administration of atropine led to decreased synthesis of VIP in the salivary glands, locus coeruleus and medulla oblongata (Hedlund et al. 1983, Petit et al. 1992). It is thus possible that in the rat heart atria, chronic atropine administration may influence synthesis of the peptide. This finding seems to be further supported by the stimulation experiments on atropinised rats that did not display any changes in the heart rate similar to those demonstrated in the control rats and by the fact that VIP concentrations reduced by chronic atropine treatment were not further decreased by intense bilateral vagus nerve stimulation.

In conclusion, chronic atropine treatment caused a decrease in VIP levels in the rat heart atria, probably due to interference with the peptide synthesis. VIP colocalised with acetylcholine in parasympathetic neurones seemed to be affected preferentially in response to vagus nerve stimulation and chronic atropine treatment, whereas the population of VIP-ergic neurones without any apparent relevance to the cholinergic neurones seems to be affected less or not at all.

\section{Conflict of Interest}

There is no conflict of interest.

\section{Acknowledgements}

The present study was supported by the Research project MSM 0021620819: Replacement of and Support to Some Vital Organs awarded by the Ministry of Education, Youth and Sports of the Czech Republic.

\section{References}

ANDERSON FL, WYNN JR, KIMBALL J, HANSON GR, HAMMOND E, HERSHBERGER R, KRALIOS AC: Vasoactive intestinal peptide in canine hearts: effect of total cardiac denervation. Am J Physiol 262: H598H602, 1992.

ANDERSON FL, KRALIOS AC, REID B, HANSON GR: Release of vasoactive intestinal peptide and neuropeptide Y from canine heart. Am J Physiol 265: H959-H965, 1993. 
ANDERSON FL, KRALIOS AC, CLUFF N, HANSON GR: Vagal-induced tachycardia: release of vasoactive intestinal peptide and peptide HI. Am J Physiol 267: H2019-H2024, 1994.

ARMOUR JA: Myocardial ischaemia and the cardiac nervous system. Cardiovasc Res 41: 41-54, 1999.

ASZTELY A, EKMAN R, TOBIN G, EKSTROM J: Depletion of vasoactive intestinal peptide and substance P in parotid glands of atropinized rats during reflex secretion. Exp Physiol 81: 297-303, 1996.

BALAS N, ARAD M, RABINOWITZ B, SHAINBERG A: Modulation of cardiac A1-adenosine receptors in rats following treatment with agents affecting heart rate. Mol Cell Biochem 231: 107-116, 2002.

BARRETT J, MCDOUGALL JJ, MORRISON JD: Enhancement by atropine of the pancreatic exocrine secretions evoked by vagal stimulation in the pithed rat. J Physiol Lond 469: 443-457, 1993.

BRUM JM, BOVE AA, SUFAN Q, REILLY W, GO VL: Action and localization of vasoactive intestinal peptide in the coronary circulation: evidence for nonadrenergic, noncholinergic coronary regulation. $J$ Am Coll Cardiol 7: 406-413, 1986.

CAWLEY TA JR, SHICKLEY TJ, RUGGIERI MR, LUTHIN GR: Effect of chronic neuroleptic treatment on central and peripheral muscarinic receptors. J Pharmacol Exp Ther 267: 134-139, 1993.

DAS DK, KALFIN R, MAULIK N, ENGELMAN RM: Coordinated Role of Vasoactive Intestinal Peptide and Nitric Oxide in Cardioprotection. Ann NY Acad Sci 865: 297-308, 1998.

DELLA NG, PAPKA RE, FURNESS JB, COSTA M: Vasoactive intestinal peptide-like immunoreactivity in nerves associated with the cardiovascular system of guinea-pigs. Neuroscience 9: 605-619, 1983.

FAHRENKRUG J: Vasoactive intestinal polypeptide: Measurement, distribution and putative neurotransmitter function. Digestion 19: 149-169, 1979.

FELICIANO L, HENNING RJ: Vagal nerve stimulation releases vasoactive intestinal peptide which significantly increases coronary artery blood flow. Cardiovasc Res 40: 45-55, 1998.

FORSGREN S: Vasoactive intestinal polypeptide-like immunoreactivity in the bovine heart: high degree of coexistence with neuropeptide Y-like immunoreactivity. Cell Tissue Res 256: 125-135, 1989.

GULBENKIAN S, SAETRUM-OPGAARD O, EKMAN R, COSTA AN, WHARTON J, POLAK JM, QUEIROZ MJ, EDVINSSON L: Peptidergic innervation of human epicardial coronary arteries. Circ Res 73: 579-588, 1993.

HALFACREE ZJ, READ PA, EDWARDS AV: Pancreatic exocrine responses to parasympathetic stimulation in anaesthetized pigs. Auton Neurosci 87: 217-224, 2001.

HAVEL PJ, DUNNING BE, VERCHERE CB, BASKIN DG, O'DORISIO T, TABORSKY GJ: Evidence that vasoactive intestinal polypeptide is a parasympathetic neurotransmitter in the endocrine pancreas in dogs. Regul Pept 71: 163-170, 1997.

HEDLUND B, ABENS J, BARTFAI T: Vasoactive intestinal polypeptide and muscarinic receptors: supersensitivity induced by long-term atropine treatment. Science 220: 519-521, 1983.

HENNING RJ, FELICIANO L, COERS CM: Vagal nerve stimulation increases right ventricular contraction and relaxation and heart rate. Cardiovasc Res 32: 846-853, 1996.

HENNING RJ, SAWMILLER DR: Vasoactive intestinal peptide: cardiovascular effects. Cardiovasc Res 49: 27-37, 2001.

HEYM C, REINECKE M, WEIHE E, FORSSMANN WG: Dopamine-beta-hydroxylase-, neurotensin-, substance P-, vasoactive intestinal polypeptide- and enkephalin-immunohistochemistry of paravertebral and prevertebral ganglia in the cat. Cell Tissue Res 235: 411-418, 1984.

HILL MR, WALLICK DW, MARTIN PJ, LEVY MN: Effects of repetitive vagal stimulation on heart rate and on cardiac vasoactive intestinal polypeptide efflux. Am J Physiol 268: H1939-H1946, 1995.

HOGAN K, MARKOS F: An investigation into the presence of a vagal tachycardia and the effect of vasoactive intestinal polypeptide on the rat heart rate in vitro. Pharmacology 76: 101-104, $2006 \mathrm{a}$.

HOGAN K, MARKOS F: Vasoactive intestinal polypeptide receptor antagonism enhances the vagally induced increase in cardiac interval of the rat atrium in vitro. Exp Physiol 91: 641-646, $2006 \mathrm{~b}$.

HOKFELT T: Neuropeptides in perspective: the last ten years. Neuron 7: 867-879, 1991.

HORÁČKOVÁ M, ARMOUR JA, BYCZKO Z: Distribution of intrinsic cardiac neurons in whole-mount guinea pig atria identified by multiple neurochemical coding. A confocal microscope study. Cell Tissue Res 297: 409-421, 1999. 
HORÁČKOVÁ M, SLAVÍKOVÁ J, BYCZKO Z: Postnatal development of the rat intrinsic cardiac nervous system: a confocal laser scanning microscopy study in whole-mount atria. Tissue Cell 32: 377-388, 2000.

KALFIN R, MAULIK N, ENGELMAN RM, CORDIS GA, MILENOV K, KASAKOV L, DAS DK: Protective role of intracoronary vasoactive intestinal peptide in ischemic and reperfused myocardium. $J$ Pharmacol Exp Ther 288: 952-958, 1994.

KRISTENSEN B, GEORG B, FAHRENKRUG J: Cholinergic regulation of VIP gene expression in human neuroblastoma cells. Brain Res 775: 99-106, 1997.

KUNCOVÁ J, SLAVÍKOVÁ J: Distribution of vasoactive intestinal polypeptide in the rat heart: effect of guanethidine and capsaicin. Ann Anat 185: 153-161, 2003.

LAPCHAK PA, BEAUDET A: Cholinergic regulation of vasoactive intestinal peptide content and release in rat frontal cortex and hippocampus. $J$ Neurochem 55: 1340-1345, 1990.

LOFFELHOLZ K, PAPPANO AJ: The parasympathetic neuroeffector junction of the heart. Pharmacol Rev 37: 1-24, 1985.

LUNDBERG JM: Evidence for coexistence of vasoactive intestinal polypeptide (VIP) and acetylcholine in neurones of cat exocrine glands. Morphological, biochemical and functional studies. Acta Physiol Scand Suppl 496: 1-57, 1981.

LUNDBERG JM: Pharmacology of cotransmission in the autonomic nervous system: Integrative aspects on amines, neuropeptides, adenosine triphosphate, amino acids and nitric oxide. Pharmacol Rev 48: 113-178, 1996.

LUNDBERG JM, ANGGARD A, FAHRENKRUG J: Complementary role of vasoactive intestinal polypeptide (VIP) and acetylcholine for cat submandibular gland blood flow and secretion. II. Effects of cholinergic antagonists and VIP antiserum. Acta Physiol Scand 113: 329-363, 1981.

MABE AM, HOARD JL, DUFFOURC MM, HOOVER DB: Localization of cholinergic innervation and neurturin receptors in adult mouse heart and expression of the neurturin gene. Cell Tissue Res 326: 57-67, 2006.

MYSLIVEČEK J, TROJAN S, TUČEK S: Biphasic changes in the density of muscarinic and beta-adrenergic receptors in cardiac atria of rats treated with diisopropylfluorophosphate. Life Sci 58: 2423-2430, 1996.

PARSONS RL, LOCKNAR SA, YOUNG BA, HOARD JL, HOOVER DB: Presence and co-localization of vasoactive intestinal polypeptide with neuronal nitric oxide synthase in cells and nerve fibers within guinea pig intrinsic cardiac ganglia and cardiac tissue. Cell Tissue Res 323: 197-209, 2006.

PETIT JM, DENOROY L, JOUVET M: Effects of chronic atropine administration on regional vasoactive intestinal polypeptide concentrations in rat brain. Eur J Pharmacol 212: 79-85, 1992.

ROOSSIEN A, BRUNSTING JR, NIJMEIJER A, ZAAGSMA J, ZIJLSTRA WG: Effects of vasoactive intestinal polypeptide on heart rate in relation to vagal cardioacceleration in conscious dogs. Cardiovasc Res 33: 392399, 1997.

SAID SI: Vasoactive intestinal polypeptide (VIP): current status. Peptides 5: 143-150, 1984.

SAID SI, MUTT V: Polypeptide with broad biological activity: isolation from small intestine. Science 169: 1217-1218, 1970.

SANCHEZ-VICENTE C, RODRIGUEZ-NODAL F, MINGUELA A, GARCIA LJ, SAN ROMAN JI, CALVO JJ, LOPEZ MA: Cholinergic pathways are involved in secretin and VIP release and the exocrine pancreatic response after intraduodenally perfused acetic and lactic acids in the rat. Pancreas 10: 93-99, 1995.

SAWMILLER DS, HENNING RJ, CUEVAS J, DEHAVEN WI, VESELY DL: Coronary vascular effects of vasoactive intestinal peptide in the isolated perfused rat heart. Neuropeptides 38: 289-297, 2004.

SCHMIDT P, RASMUSSEN TN, HOLST JJ: Release of immunoreactive somatostatin, vasoactive intestinal polypeptide (VIP), and galanin during propulsive complexes in isolated pig ileum. Peptides 14: 215-220, 1993.

SHVILKIN A, DANILO P JR, CHEVALIER P, CHANG F, COHEN IS, ROSEN MR: Vagal release of vasoactive intestinal peptide can promote vagotonic tachycardia in the isolated innervated rat heart. Cardiovasc Res 28: 1769-1773, 1994.

SLAVÍKOVÁ J: Distribution of peptide-containing neurons in the developing rat right atrium, studied using immunofluorescence and confocal laser scanning. Neurochem Res 22: 1013-1021, 1997.

STEELE PA, GIBBINS IL, MORRIS JL: Projections of intrinsic cardiac neurons to different targets in the guinea-pig heart. J Auton Nerv Syst 56: 191-200, 1996. 
TOBIN G, EKSTROM J, BLOOM SR, EDWARDS VA: Atropine-resistant submandibular responses to stimulation of the parasympathetic innervation in the anaesthetized ferret. $J$ Physiol Lond 437: 327-339, 1991.

TOBIN G, EKSTROM J, EKMAN R, HAKANSON R: Influence of atropine on the depletion of vasoactive intestinal peptide, substance $\mathrm{P}$ and calcitonin gene-related peptide from rat parotid gland in response to parasympathetic nerve stimulation. Acta Physiol Scand 150: 463-465, 1994.

UNO Y, MATSUMURA K, SCHEFFEL U, WILSON AA, DANNALS RF, WAGNER HN JR: Effects of atropine treatment on in vitro and in vivo binding of $4-\left[{ }^{125} \mathrm{I}\right]$-dexetimide to central and myocardial muscarinic receptors. Eur J Nucl Med 18: 447-452, 1991. 